$$
\text { Postprint - Journal of Environmental Management 247: 756-765 (2019) }
$$

\title{
Implications of mycoremediated dry olive residue application and arbuscular mycorrhizal fungi inoculation on the microbial community composition and functionality in a metal- polluted soil.
}

\author{
Mercedes García-Sánchez $a^{a^{*}}$, Tomáś Cajthaml ${ }^{b c}$, Alena Filipová ${ }^{b c}$, Pavel Tlustoša , Jirina \\ Szákováa , Inmaculada García-Romera ${ }^{d}$
}

${ }^{a}$ Department of Agro-Environmental Chemistry and Plant Nutrition. Faculty of Agrobiology, Food and Natural Resources. Kamýcká CZ-129 Prague 6, Czech Republic.

${ }^{b}$ Institute of Microbiology, Academy of Sciences of the Czech Republic, v.v.i., Videnská 1083, CZ14220 Prague 4, Czech Republic

'Institute of Environmental Studies, Faculty of Science, Charles University. Benátská 2, CZ-128 01 Prague 2, Czech Republic

${ }^{d}$ Department of Soil Microbiology and Symbiotic Systems. Estación Experimental del Zaidin, Consejo Superior de Investigaciones Científica (EEZ-CSIC). C/ Profesor Albareda 1, C.P. 18001, Granada, España.

${ }^{*}$ Corresponding author:

Mercedes García-Sánchez

Department of Agro-Environmental Chemistry and Plant Nutrition. Faculty of Agrobiology, Food and Natural Resources. Kamýcká CZ-129, Prague 6, Czech Republic. 
email: garcia.sanchez.mercedes@gmail.com

Present address: Institut National de Recherche Agronomique (INRA)-UMR Eco\&Sols, 2 Place Viala, 34060 Montpellier, France. 


\section{Abstract}

Metal-polluted soils represent hostile environments affecting the composition and functions of soil microbial communities. This study evaluated the implication of combining the mycoremediated dry olive residue (MDOR) amendment application with the inoculation of the arbuscular mycorrhizal fungi (AMF) Funneliformis mosseae in restoring the quality, composition, and functionality of soil microbial communities. To achieve this aim, a mesocosms experiment was set up that included three variations: i) with and without application of Penicillium chrysogenum10-transformed MDOR (MDOR_Pc), and Chondrosterum purpureum-transformed MDOR (MDOR_Cp) amendments; ii) with and without F. mosseae inoculation; and iii) 30-day and 60day soil treatment time. As a result of this combined treatment, changes in the soil labile organic $\mathrm{C}$ and $\mathrm{N}$ fractions were observed throughout the experiment. Increases in the abundance of phospholipid fatty acids (PLFAs) for bacteria, actinobacteria, and Gram- and Gram+ bacteria were also recorded at the end of the experiment. The addition of MDOR amendments boosted fungal and AM fungi communities. AM fungi root and soil colonization was also enhanced as the result of improvement nutrient turnover and spatial conditions caused by adding MDOR in combination with an inoculation of $F$. mosseae. The composition and functionality of microbial communities seemed to be an important ecological attribute indicating an apparently fully functional restoration of this metal-polluted soil and therefore suggesting the suitability of the combined MDOR and AM fungus treatment as a reclamation practice.

Key words: Funneliformis mosseae; Metal-pollution; Microbial activities; Mycoremediated dry olive residue (MDOR); Phospholipid fatty acids (PLFAs); Soil restoration. 


\section{Introduction}

Soils affected by mining and smelting activities can represent adverse and hostile environments for living organisms as the result of the accumulation of available metals, acidic $\mathrm{pH}$, lack of organic matter (OM) and nutrients, and the poor structure of aggregates (Epelde et al., 2014). The presence of metals can negatively affect the turnover of soil microorganisms and soil respiration and their activities, thus altering nutrient cycles (Giller et al., 2009). Therefore, strategies to improve the quality of metal-polluted soils are needed to guarantee the restoration and functioning of ecosystems. The incorporation of organic amendments to metal-polluted soils has been suggested as a suitable option for enhancing the soil $\mathrm{pH}, \mathrm{OM}$ content, and the microbial structure and functionality with subsequent metal bioavailability reduction (García-Sánchez et al., 2015a, b). Among the different organic amendments, such as, anaerobic digestion residues (digestate) and/or composts, used in recovering of metal degraded-soil (Alvarenga et al., 2008; Epelde et al., 2014; García-Sánchez et al., 2015a; Zornoza et al., 2015), the application of mycoremediated dry olive residue (MDOR) has resulted in a profitable strategy in decreasing the bioavailability of metals (Hovorka et al., 2016). The MDOR, which consists of the biological transformation of dry olive residue (DOR) through different species of saprophytic fungi with potential abilities to convert/transform the DOR into a suitable soil amendment (mycoremediation), has been reported as an environmentally sound management option for its use as an organic amendment, as previously observed by Sampedro et al. (2004). The fungal transformation is due to the production of a set of extracellular oxidoreductases by fungi that have enormous potential to degrade DOR's toxic substances (Reina et al., 2013, 2017). The mycoremediation of DOR also implies a degree of humification, as the result of the fungal OM transformation; this also favors 
stabilization prior to soil application as a suitable organic amendment (Sampedro et al., 2007, 2009a; Siles et al., 2014a, b). Such characteristics suggest that MDOR could be used as an organic amendment for recovering the quality and functionality of metal-polluted soils.

Arbuscular mycorrhizal fungi (AMF) are globally distributed soil microorganisms that form a symbiotic association with more than $80 \%$ of terrestrial plants (Smith and Read, 2008). The AMF confer multiple benefits to plants by increasing soil nutrient uptake, and improving plant water relationship, stability of soil aggregates, and plant protection against metal toxicity (Meier et al., 2012; Philippot et al., 2013; Veresoglou and Rillig 2012). Although the ability of AMF to explore environments degraded by metals has been reported, the diversity and abundance decrease with increasing metal content, and some strains are more resistant than others (Hildebrandt et al., 2007; Zarei et al., 2010). However, Alguacil et al. (2011) and Montiel-Rozas et al. (2016) have reported significant increases in the diversity of AM fungal populations associated with shrub roots as well as their adaptation to different levels of contamination as the result of the application of organic amendments in historically metal-polluted areas. In addition, these results are consistent with the findings that demonstrated shifts in the microbial community composition and functionality in a metal-polluted soil through the combination of adding fermented organic wastes and inoculating with AM fungus (Kholer et al., 2016). The evidence suggests the combination of AM fungi with organic amendments could result in the establishment of a fully-functional soil microbial community that will lead to monitoring programs to ensure the restoration of soil functions.

To date, MDOR has shown potential for the stabilization of metals such as $\mathrm{Cd}, \mathrm{Pb}$, and $\mathrm{Zn}$ (Hovorka et al., 2016; García-Sánchez et al., 2017). A combined treatment involving MDOR and AM fungus application has only been studied in terms of percentages of root colonization and plant biomass (Sampedro et al., 2008). Therefore, the role of the interaction of AM fungus and MDOR 
addition on the microbiological soil attributes of ecological relevance has scarcely been studied. In this view, we hypothesized that combining treatment with MDOR amendments and AM fungus applications would be a sustainable means of restoring the functions in a metal-polluted soil. To probe this hypothesis, we evaluated the influence on the soil quality, composition, and functionality of microbial communities of Penicillium chrysogenum-10-transformed MDOR (MDOR_Pc), and Chondrosterum purpureum-transformed MDOR (MDOR_Cp) application along with the AM fungus, Funneliformis mosseae, inoculation. MDOR amendments were chosen according to their different fungal ability in decreasing DOR toxic substances, which in turn might lead to differences in relation to the degree of organic matter humification (Sampedro et al., 2004; 2007; 2009a; Reina et al., 2013; 2017; García-Sánchez et al., 2017) and thus, induce difference soil response. $F$. mosseae was selected as a suitable mycorrhizal inoculum because it has been reported as the most abundant AMF in soil metal-polluted soils (Alguacil et al., 2011). Soil chemical parameters [C $\left(\mathrm{C}_{\text {tot }}, \mathrm{TOC}\right.$, and WSOC) and $\left.\mathrm{N}\left(\mathrm{N}_{\mathrm{tot}}\right)\right]$, the composition of phospholipid fatty acids (PLFAs), and neutral lipid fatty acids (NLFA), and the analysis of microbial activities (dehydrogenase, arylsulphatase, $\beta$-glucosidase, phosphatase, and protease) were measured as ecological attributes to evaluate the sustainability of this practice in recovering the functioning of this metal-polluted soil.

\section{Material and Methods}

\subsection{Soil description and sampling}

The soil samples studied in this experiment were collected close to Trhové Dušníky village, which is located in the Př́bam district of the Czech Republic. Polymetallic mineral deposits, such as $\mathrm{Pb}, \mathrm{Cd}$, and $\mathrm{Zn}$, have accumulated extensively in this soil during recent years as the result of intense regional mining and smelting activities. A detailed description of the study area has been 
published elsewhere (Vaněk et al., 2005). According to the FAO (2006), this soil is classified as Fluvisol; its physico-chemical and microbiological characteristics are shown in Table 1 and 2. All soil samples were obtained by mixing sub-samples collected from different zones of the field area at a depth of 0-20 cm. Subsequently, the soil was homogenized, air-dried at room temperature, and finally passed through a $5 \mathrm{~mm}$ mesh sieve. The soil was stored in polythene bags until its use.

\subsection{Biological transformation of DOR (mycoremediation)}

The fungi used for the mycoremediation of the DOR were P. chrysogenum-10 (EEZ 10) and $C$. purpureum (DSMZ4894). The fungi were pre-cultured on $2 \%$ MEA for 2 weeks at $24{ }^{\circ} \mathrm{C}$ to maintain the fresh inoculum. DOR was collected from the manufacturing company Sierra Sur S.L. (Granada, Spain), and then was sterilized by autoclave 3 times $\left(121^{\circ} \mathrm{C}\right.$ for $\left.20 \mathrm{~min}\right)$ and then frozen at $-20{ }^{\circ} \mathrm{C}$ until use.

The mycoremediation of DOR was done using the solid state fermentation to accelerate the fungi abilities in DOR transformation as previously described by Reina et al. (2013). For this purpose, Erlenmeyer flasks $(250 \mathrm{~mL})$ were initially used to pre-culture the fungi in a barley-based medium (18 $\mathrm{g}$ of barley seeds and $30 \mathrm{~mL}$ of sterile water). The content of 4 fungal agar plates homogenized in $80 \mathrm{~mL}$ of sterile water $(55 \% \mathrm{v} / \mathrm{w})$ was used to inoculate the barley seeds. After 1 week of growing, the barley-seed media inoculated with fungi were mixed with sterile DOR (50\% w/w), and moistened with sterile water. Flasks with barley-seed media non-fungi-inoculated were also mixed with DOR and used as control. The experiment was conducted in triplicate. The MDOR_Pcand MDOR_Cp amendments were collected after 4 weeks of incubation and sterilized by autoclaving. Thereafter, samples were sieved ( $2 \mathrm{~mm}$ mesh), manually homogenized, and kept at $4{ }^{\circ} \mathrm{C}$. Before setting up the experiment, both DOR and MDOR amendments (MDOR_Pc and MDOR_Cp) were characterized, and their chemical properties are shown in Table 1. 


\subsection{Arbuscular mycorrhizal fungi (AMF) inocula and quantification}

The AM fungus used in this experiment was F. mosseae (formerly Glomus mosseae); the mycorrhizal inoculum was obtained using trap-pot cultures of Medicago sativa L., consisting of soil, spores, mycelia, and colonized root fragments (10 sporocarps $\mathrm{g}^{-1}$, with $1-5$ spores per sporocarp). The percentage of mycorrhizal fungi root length infected was estimated using the methodology described by Giovannetti and Mosse (1980) after the root system was cleared and stained (Phillips and Hayman, 1970). The external mycelium was extracted by sieving $3 \mathrm{~g}$ of fresh soil through 700 and $100 \mu \mathrm{m}$ sieves. The material retained in the $100 \mu \mathrm{m}$ sieve was transferred to a nylon membrane $(32 \mu \mathrm{m})$ and stained with fuchsine acid solution $(0.05 \%)$ and then hyphae length was quantified under a stereoscopic microscope at 100× (Giovannetti and Mosse, 1980).

\subsection{Experimental set up}

The experiment was set up in a series of identical polypropylene pots with an individual total volume of $0.3 \mathrm{~L}$. Approximately $300 \mathrm{~g}$ of metal-polluted soil was placed in each pot. The experimental design consisted of a randomized factorial system with three factors of variation consisting of two levels. The first factor comprised soil with and without MDOR amendment application; the second one included soil with and without $F$. mosseae inoculation; the third consisted of the experimental conditions, 30 and 60 days of soil treatment. MDOR amendments, MDOR_P $c$ and MDOR_Cp, were applied and manually mixed with the soil to reach concentrations of $50 \mathrm{~g} \mathrm{~kg}^{-1}$, as previously reported by Siles et al. $(2014 \mathrm{a}, \mathrm{b})$. One half of the amended pots were inoculated with $F$. mosseae by adding $8 \mathrm{~g}$ of inoculum, as suggested by García-Sánchez et al. (2014); meanwhile, the other half received the same weight of inoculum filtrate (Whatman no. 1 filter paper) containing soil microbiota free of AM fungal propagules. Soil samples with and 
without DOR application and F. mosseae inoculation were also set up and used as a control. The moisture of the soil was brought to $60 \%$ of the soil water holding capacity. Five replicates were established for each treatment. One 15-day-old wheat plant (Triticum aestivum L.) was planted in each pot. The experiment was run in greenhouse conditions (supplementary light $25 / 19{ }^{\circ} \mathrm{C}$ and 50 $\%$ relative humidity) and plants were regularly watered in order to maintain the same initial moisture conditions. After 30 and 60 days of experiment, soil samples from each pot were homogenized, sieved ( $2 \mathrm{~mm}$ mesh), and subdivided into three subsamples. The first subsample was air-dried at room temperature for chemical analysis, the second was kept at $4{ }^{\circ} \mathrm{C}$ for biochemical analysis, and the third was frozen at $-80^{\circ} \mathrm{C}$ and then freeze-dried for PLFA and NLFA analyses. Wheat plants were also harvested and the weight of the shoots and roots were recorded after drying the material at $105^{\circ} \mathrm{C}$ for $72 \mathrm{~h}$.

\subsection{Chemical analysis}

The content in total $\mathrm{C}\left(\mathrm{C}_{\text {tot }}\right)$ and $\mathrm{N}\left(\mathrm{N}_{\text {tot }}\right)$ was determined using a CNS analyzer (Leco Corp., St. Joseph, MI, USA). Total organic carbon (TOC) was assayed by the wet oxidation method proposed by Mingorance et al. (2007). The reaction was carried out with $3 \mathrm{~mL} \mathrm{~K}_{2} \mathrm{Cr}_{2} \mathrm{O}_{7}$ and $6 \mathrm{~mL}$ $\mathrm{H}_{2} \mathrm{SO}_{4}$, and the $\mathrm{Cr}^{3+}$ resulting from organic $\mathrm{C}$ oxidation were determined using spectrophotometry (590nm). The water soluble organic carbon (WSOC) of soil samples was extracted with de-ionized water at 1:10 [soil:water (w/v)] and the organic carbon was quantified using the same methodology as mentioned above.

\subsection{PLFA and NLFA analysis}

The PLFAs were extracted from $1 \mathrm{~g}$ of freeze-dried soil samples with a mixture of chloroform-methanol-phosphate buffer (1:2:0.8, v/v/v), as previously described by Bligh and Dyer (1959). Thereafter, the lipids were fractioned into neutral lipids (NLFA), glycolipids, and polar lipids (PLFAs), using an extraction cartridge (LiChrolut Si-60, Merck, White-house Station, USA), 
and then NLFA and PLFA were subjected to mild alkaline methanolysis, as described by Šnajdr et al. (2008). The free methyl esters of NLFA and PLFAs were analyzed by gas chromatographymass spectrometry (450-GC, 240-MS ion trap detector, Varian, Walnut Creek, CA), following the same procedure described by Sampedro et al. (2009b).

The soil microbial community composition was determined using the following PLFAs:

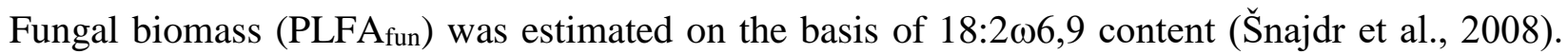

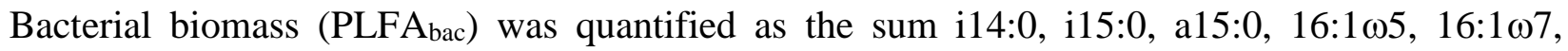

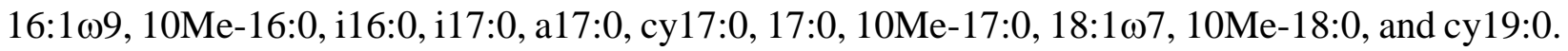
Actinobacterial biomass $\left(\right.$ PLFA $_{\text {act }}$ ) was determined according to 10Me-16:0, 10Me-17:0, and 10Me-18:0. The $\Sigma$ PLFAs content was used to estimate the total microbial biomass (PLFA tot). The NLFA 16:1 $\omega 5$ was assigned as a marker for the quantification of AM fungi (Olsson et al., 2003). Different microbial ratios F/B [(PLFA fun $/$ PLFA $\left.\left._{\text {bac }}\right)\right]$, G+/G- $[($ Gram-positive/Gram-negative

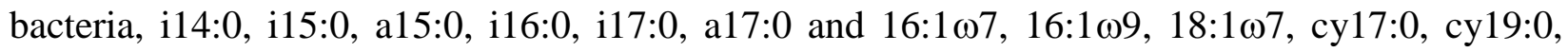
respectively)], F/AMF [(PLFA fun $\left.\left./ \mathrm{NLFA}_{\mathrm{AMF}}\right)\right]$ stress indicators [cy/pre ((cy17:0+cy19:0)/

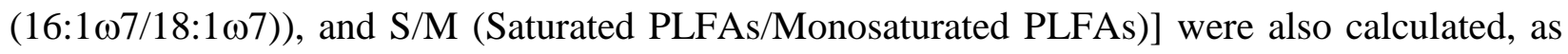
Siles et al. (2014a) previously described.

\subsection{Enzymatic activities}

Dehydrogenase activity (EC 1.1) was quantified according to the García et al. (1997) method. Arylsulphatase (EC 3.1.6.1), phosphatase (EC 3.1.3.1), and $\beta$-glucosidase (EC 3.2.1.30) were assessed following the method described by Tabatabi and Bremer (1970) and Eivazi and Tabatabai $(1977,1988)$, respectively. Protease activity (EC 3.4.2.21-24) was determined according to the Ladd and Butler (1972) method. 


\subsection{Statistical analysis}

MDOR amendment applications, AM fungus inoculation, and time of soil treatment effects and their interactions on parameters measured were analyzed by a factorial analysis of the variance (ANOVA). Comparison of means was performed using the Tukey test at three levels of significance: ${ }^{*} \mathrm{p}<0.05 ; * * \mathrm{p}<0.01 ; * * * \mathrm{p}<0.001$, using the SPSS software version 17.0.

\section{Results}

\subsection{Effect of MDOR amendment application and AM fungus inoculation on soil chemical} parameters

As shown in Table 3, the application of MDOR amendments to soil samples non-inoculated with the AM fungus resulted in an increase in the $\mathrm{C}_{\text {tot }}, \mathrm{TOC}$, WSOC and $\mathrm{N}_{\text {tot }}$ content in comparison with those non-amended soil samples $(P<0.001, P<0.001, P<0.001, P<0.001$, respectively). Interestingly, the application of MDOR_Pc resulted in a significant increase of the WSOC content in relation to MDOR_Cp. A decline was detected in WSOC content $(\mathrm{T}, P<0.001)$ in MDORamended soil samples after 60 days of experiment; however, the interaction between MDOR amendments and time had a significant effect on $\mathrm{C}_{\text {tot }}$ and $\mathrm{N}_{\text {tot }}$ values $(\mathrm{MDOR} \times \mathrm{T}, \mathrm{P}<0.001, \mathrm{P}<0.001)$ (Table 3). The presence of the AM fungus provoked a significant increase in the $\mathrm{C}_{\text {tot }}$, and $\mathrm{N}_{\text {tot }}$ content (Table 3), whereas the WSOC content experienced a significant decline (AMF, $\mathrm{P}<0.01$, $\mathrm{P}<0.01, \mathrm{P}<0.05$, respectively). Interestingly, neither the AM fungus nor the MDOR amendments had a significant effect on $\mathrm{C}_{\text {tot }}$, and/or WSOC values; however, the interaction amongst MDOR amendments, AM fungus and time resulted in a significant decrease in $\mathrm{N}_{\text {tot }}$ content $(\mathrm{MDOR} \times \mathrm{AMF} \times \mathrm{T}, \mathrm{P}<0.001)$. 
3.2. Effect of MDOR amendment application and AM fungus inoculation on the abundance and composition of soil microbial communities.

The application of MDOR amendments to soil samples significantly increased all microbial groups, measured as the amount of $\operatorname{PLFA}_{\text {tot }}(P<0.001), \operatorname{PLFA}_{\text {fun }}(P<0.001), \operatorname{PLFA}_{\text {bac }}(P<0.001)$, PLFA $_{\text {act }}(P<0.001)$, PLFA $_{\text {Gram }}(P<0.001)$, PLFA Gram- $(P<0.001)$, and NLFA AMF $(P<0.001)$, in relation to non-amended soil samples (Table 4). Likewise, a generalized enhancement in the markers for $\mathrm{PLFA}_{\text {tot }}, \mathrm{PLFA}_{\mathrm{bac}}, \mathrm{PLFA}_{\mathrm{act}}, \mathrm{PLFA}_{\mathrm{Gram}+}, \mathrm{PLFA}_{\mathrm{Gram}}$ - and NLFA was recorded as the result of the interaction between MDOR amendment application and time of soil treatment (MDOR $\times$ T; $P<0.001 ; P<0.001 ; P<0.001 ; P<0.001$, respectively)(Table 4). There was not any effect in terms of fungal proliferation after 60 days of experiment (MDOR $\times \mathrm{T} ; P=0.5398$ ) (Table 4). The inoculation of the AM fungus, F. mosseae, stimulated all microbial groups and increased the related PFLA for total biomass $(P<0.001)$, fungal $(P<0.001)$, bacterial $(P<0.001)$, actinobacteria $(P<0.001)$, Gram $+(P<0.001)$, and Gram- $(P<0.001)$, whilst the amount of NLFAAMF $_{A}(P<0.001)$ declined compared to non-inoculated soil samples. Surprisingly, the interaction between AM fungus inoculation and time of soil treatment resulted in a generalized and drastic decrease of PLFA values for actinobacteria, Gram+ and Gram-, conversely, as it was found in the case of NLFA (AMF $\times$ T; $P<0.01$; PLFA $_{\text {act }}, P<0.001$; PLFA $_{\mathrm{Gram}+}, P<0.001$; $\mathrm{PLFA}_{\mathrm{Gram}}$, $P<0.01$; NLFA, $P<0.001$ ) (Table 4). The combined treatment involving MDOR and AM fungus significantly declined the proliferation of all microbial groups (MDOR $\times$ AMF; $\mathrm{PLFA}_{\mathrm{tot}}, P<0.001$;

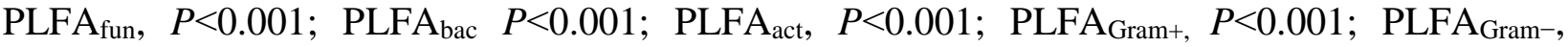
$P<0.001$ ), whilst AMF-related NLFA resulted in a significant enhancement (MDOR $\times$ AMF; $P<0.001$ ) (Table 4). The interaction amongst MDOR amendment application, AM fungus inoculation, and time of soil treatment resulted in significant differences. For instance, total 
biomass, bacterial, actinobacterial Gram+ and Gram- communities were enhanced by adding MDOR amendments (MDOR $\times$ AMF $\times$ T; $P<0.001, \quad P L F A_{\text {tot }} ; \quad P<0.001, \quad$ PLFA $_{\text {act }} ; \quad P<0.001$, PLFA $_{\text {Gram }+} ; P<0.001$, PLFA $_{\text {bac }} ; P<0.001$, PLFA $\left._{\text {Gram}-}\right)$. Meanwhile, the AMF-related NLFA were reduced at the end of the experiment $\left(\mathrm{MDOR} \times \mathrm{AMF} \times \mathrm{T} ; P<0.001, \mathrm{NLFA}_{\mathrm{AMF}}\right)($ Table 4$)$.

In order to evaluate the impact of the interaction of MDOR amendment application and AM fungus inoculation during the experiment on the physiological status of the microbial communities, different ratios such as F/B, Gram+/Gram-, F/AMF, cy/pre, and S/M were calculated (Table 5). Thus, the Gram+/Gram-, and F/AMF ratios experienced a significant increase when MDOR amendments were applied to soil in comparison with non-amendment soil samples $(P<0.01$; $P<0.01$, respectively). However, MDOR amendment application to soil samples provoked a generalized decline in the Gram+/Gram-, cy/pre, and S/M ratios in comparison to non-amended soil samples after 60 days of experiment (MDOR $\times$ T, $P<0.001 ; P<0.05 ; P<0.05$ ) (Table 5). The inoculation of $F$. mossease significantly increased the F/AMF ratio $(P<0.001)$, whilst a decrease in the $\mathrm{F} / \mathrm{B}, \mathrm{cy} / \mathrm{pre}$, and $\mathrm{S} / \mathrm{M}$ ratios was found in comparison to non-inoculated soil samples $(P<0.001$; $P<0.001 ; P<0.001$, respectively). Interestingly, an opposite trend was found in the F/AMF ratio as the result of the interaction between AM fungus inoculation and time of soil treatment after 60 days of experiment (AMF $\times \mathrm{T}, P<0.05$ ) (Table 5). The $\mathrm{F} / \mathrm{B}$ ratio experienced an increase as consequence of MDOR amendment application to AM fungus inoculated soil samples, whilst an opposite trend was found in the F/AMF ratio in relation to the $F$. mosseae-inoculated soil samples (MDOR $\times$ AMF, $P<0.01 ; P<0.01$, respectively). A generalized decline in Gram+/Gram-, cy/pre, and S/M ratios was found as consequence of the MDOR amendment application and AM fungus treatment at the end of the experiment (MDOR $\times \mathrm{AMF} \times \mathrm{T}, P<0.05 ; P<0.01 ; P<0.01)$ (Table 5). 


\subsection{Effect of MDOR amendment application and AM fungus inoculation on the soil microbial}

activities.

The application of MDOR amendments positively affected the activity of the dehydrogenase, protease and arylsulphatase activities in relation to non-amended soil samples (Fig. 1a, d, and e). A generalized increase in arylsulphatase activities were recorded when MDOR amendments were applied to soil samples after 60 days of experiment (Fig. 1d). The inoculation of $F$. mosseae had a negative impact on the $\beta$-glucosidase, and arylsulphatase activities, whilst phosphatase activity was positively affected. However, the phosphatase activity was significantly declined after 60 days of experiment (Fig. 1c). Overall, the combined treatment with MDOR amendments and AM fungus increased the $\beta$-glucosidase and arylsulphatase activities compared to inoculated soil samples (Fig. 1b, and d). Likewise, the activity of the $\beta$-glucosidase experienced a decrease as the result of combining MDOR amendments and AM fungus at the end of the experiment when MDOR_Cp was applied, whereas the opposite trend was found in the case of the arylsulphatase activity (Fig. 1b, and d).

3.4. Effect of MDOR amendment application and AM fungus inoculation on mycorrhizal colonization

The percentage of root colonization by AM fungi was generally lower as the result of MDOR amendment application; however, the extraradical mycelium was slightly enhanced following the application of MDOR_Cp $(P<0.001)$ (Fig. 2a, b). Similarly, the inoculation of soil samples with $F$. mosseae resulted in a similar percentage of root colonization to that reached in non-inoculated soil samples, but increased the external hyphae length (Fig. 1a, b). The combined treatment involving MDOR amendments and AM fungus treatment resulted in higher levels of percentage of root colonization, especially by adding MDOR_ $C p$, whilst both MDOR amendments significantly boosted the extraradical mycelium (Fig. 1a, b). 


\section{Discussion}

\subsection{Chemical variables}

Our results demonstrated that the MDOR amendment application had an important effect that considerably increased the $\mathrm{C}$ pools in the metal-polluted soil during the experiment. The exogenous input of organic C compounds, through olive mill-waste compost applications, contributed to the enhancement of the organic carbon content in metal-polluted soils (Alburquerque et al., 2011; Pardo et al., 2011, 2014). In our study, we recorded noticeable increases in the watersoluble $\mathrm{C}$ fraction (WSOC) throughout the experiment. This fraction consists of a heterogeneous mixture of components varying in molecular weight (Alguacil et al., 2008). Application of MDOR amendments can supply labile C compounds, which can be used as a source of energy by microorganisms, thereby leading to the improvement of the mineralization of the organic matter in the metal-polluted soil amended with MDOR, as suggested by Alburquerque et al. (2011). A previous study conducted by Siles et al. (2014a) reported similar results by adding $F$. flocossatransformed MDOR and Fusarium oxysporum-transformed MDOR to degraded soils. The fungal transformation of DOR might lead to the formation of organic fractions, some of which may be assigned to humic substances, which can vary according to the species of fungi used to transform the DOR into an organic amendment (Sampedro et al., 2007, 2009a). However, we did not observe differences in terms of WSOC content when MDOR_Pc and MDOR_Cp were applied to soil, therefore we could assume similar degree of OM stabilization in both MDOR amendments as the result of fungal transformation. Nevertheless, a further study identifying the humic and fulvic fractions formed during the DOR's mycoremediation would be needed in order to verify this hypothesis. 
In the same vein, increases in $\mathrm{N}_{\text {tot }}$ content have also been suggested after olive-mill residue compost applications (Alburquerque et al., 2011; López-Piñero et al., 2011). Thus, the presence of MDOR amendments significantly increased the content in $\mathrm{N}_{\text {tot.. }}$ The benefit of AMF in the plant rhizosphere relies on supplying immobile phosphorus to plants in return for plant carbon sources (Fitter et al., 2011). AM fungi are unlikely to play a direct role in OM decomposition, but changes to the content in $\mathrm{C}_{\text {tot }}$ and WSOC observed in the presence of $F$. mosseae during the experiment may be associated with rhizodeposition processes and their consequent influence on microbial communities, which in turn are influenced by factors such as AM colonization (Jones et al., 2009; Bird et al., 2011). AM fungi can enhance the rate of decomposition of native soil $\mathrm{OM}$ and can acquire $\mathrm{N}$ from organic sources and also transfer to plants through its interactions with the bacterial community (Leigh et al., 2011). In our study, the changes associated with $\mathrm{N}$ content throughout the experiment would indicate the ability of $F$. mosseae not only to increase the mobilization of a substantial amount of $\mathrm{N}$ for their own growth but also to enhance plant fitness, as suggested Hodge and Fitter (2010). The combined treatment, involving MDOR amendment application and AM fungus inoculation, resulted in the additive effect as the result of the enhancement in the water soluble $\mathrm{C}$ substances throughout the experiment.

\subsection{Abundance and composition of microbial communities}

PLFAs and NLFA have been broadly used to create a profile of fingerprints of the community structure using biomarkers for specific groups of microorganisms (Bååth et al., 2003; Olsson et al., 2003) and so are useful indicators of soil attributes to evaluate the recovery of the ecological soil functions, as Covino et al. recently suggested (2016). In our study, the highest proliferation of microbial biomass, in terms of fungal, bacterial, actinobacterial, and AMF populations was reached through MDOR_P $c$ and MDOR_Cp application. This result is consistent 
with the increases in the $\mathrm{C}$ pools previously reported, which might suggest the improvement of the quality of this metal-polluted soil, as the result of the MDOR amendment application. This finding is in line with the previous shifts found in the markers for PLFAs by adding MDOR amendments with different fungi strains to soils (Sampedro et al., 2009b; Siles et al., 2014a). In addition, this was also consistent with the increases found in the F/B, Gram+/Gram-, and F/AMF ratios, which also reinforce the fact that MDOR amendments promoted better conditions for the proliferation of fungi and Gram+ bacteria in this metal-polluted soil. Higher values in the ratios cy/pre and S/M have been suggested to indicate reductions in bacterial growth rates due to nutrient limitations, and therefore they can be considered markers of physiological stress (Siles et al., 2014a). In our study, both cy/pre and S/M ratios, showed lower values in comparison with non-amendment soil samples, indicating an input of easily decomposable nutrients supplied by adding MDOR amendments, which prompted the proliferation of microbial populations. Interestingly, the inoculation of AM fungus had a strong impact on the composition of the soil microbial populations. The results indicated that all groups of microorganisms were dramatically affected by the presence of $F$. mosseae; except fungal communities, which were shown to be less affected and also corroborate the higher values in the F/AMF ratio. In addition, the increases found in the cy/pre and S/M ratios were also in line with this finding, suggesting that the inoculation of $F$. mosseae probably resulted in competition for nutrients. This result is unsurprising and is, moreover, consistent with previous evidence of the suppressive effect of $F$. mosseae on many groups of soil microorganisms, as Welc et al. reported (2010). The reason for this suppressive effect might also be due to a production of antagonistic metabolites by AM fungus exudates, as has been reported for Glomus sp. (Toljander et al., 2007). We must also consider that the type of plant used in this experiment might be responsible for the detrimental effect of the AM fungus on the microbial composition, as Welc et 
al. (2010) and Kholer et al. (2016) previously suggested. The role of the MDOR and AM fungus interaction resulted in a significant decline of all groups of microorganisms, whilst AMF relatedNLFA was positively affected during the first 30 days of the experiment. This fact might be caused by a priming effect, through MDOR amendment application, of saprophytic microorganisms solubilizing inorganic nutrients essential for the AM hyphal growth which consistently reduced the microbial population in favor of AM fungal communities. However, other studies related this effect to a better soil aggregate stability from adding organic amendments to metal-polluted soils (Zornoza et al., 2015; 2016), leading to a more suitable physical growing space for AM fungus than saprophytic fungi, as also indicated by the low F/AMF ratio. The combined treatment, involving MDOR amendment application and F. mosseae inoculation, provoked the proliferation of bacterial and Gram- bacteria populations over fungal communities at the end of the experiment, which was also supported by the lower values found in the F/B and Gram+/Gram- ratios. This finding might suggest that Gram- bacteria were adapted to more quickly to adverse and hostile conditions found in this metal-polluted soil, probably as a result of the rapid process of organic $\mathrm{C}$ substance decomposition by fungal communities with utilization shifting to bacterial Gramcommunities, as previously reported by Kholer et al. (2016). Interestingly, the proliferation of the actinobacteria populations was consistent with the increases in the Gram+ bacteria found as the result of the MDOR_Pc and MDOR_Cp application in combination with AM fungus inoculation, respectively, at the end of the experiment. This result is in line with other studies, which have revealed that the application of organic amendments to metal-polluted soils considerably increased the population of Gram+ bacteria (Fernández et al., 2012; Kholer et al., 2016). Therefore, a more marked improvement in the functioning and physiological status of this metal-polluted soil might be suggested by adding MDOR_Pc and MDOR_Cp along to F. mosseae, an idea also supported 
by the lower values in cy/pre and S/M ratios at the end of the experiment. However, this interaction negatively affected the AMF-related NLFA, which is contradictory with the fact that Gram+ bacteria could have a positive effect on the proliferation of AM fungi (Artursson et al., 2006); however, the increase found in the F/AMF ratio might suggest that saprophytic fungi had an antagonistic effect on AM fungi population. Nevertheless, regardless of this finding, changes in the diversity of AM fungi populations might be expected in response to amendment applications, as Montiel-Rozas et al. (2016) recently suggested, in a historically metal-polluted soil amendment with olive mill residue compost.

\subsection{Activity of microbial communities}

Soil microbial activity provides a suitable estimate of the overall metabolic activity or metabolism of soils because microbes are sensitive to soil disruptions, such as metals, or on the contrary, to the addition of exogenous organic $\mathrm{C}$ compounds like organic amendments (Calvarro et al., 2014; García-Sánchez et al., 2015a). In our study, the MDOR amendment applications provoked a generalized enhancement in the dehydrogenase, arylsulphatase and protease activities. However, as the set of extracellular enzymes produced during the fungal transformation of DOR is diverse (Reina et al., 2013; 2017), changes in relation to humic and fulvic fractions in MDOR might be expected, leading to different responses in each enzyme assayed. Thus, higher available organic N compounds in MDOR_Pc might be responsible for the higher protease activity. This finding is also consistent with the previous enhancement found in the $\mathrm{C}$ and $\mathrm{N}$ pools, which contain carbon, and energy sources by soil microbial activity. The content in $\mathrm{S}$ found in MDOR amendments, as indicated by the chemical composition (Table 1), would probably be responsible for the increases found in arylsulphatase activity. Siles et al. (2014b) reported a similar response in this set of enzymes during the reclamation of degraded soils followed by the application of MDOR amendments with different fungal strains. AM fungi may stimulate the microbial activity indirectly, 
by changing root exudate patterns (Rodríguez-Caballero et al., 2017), or directly, via rhizodeposition. In our case, the presence of $F$. mosseae in the rhizosphere of wheat plants would lead to decreases in all microbial activities assayed, except phosphatase, throughout the experiment. The increase in phosphatase activity was unsurprising, and even expected, owing to the role of AM fungi in the mobilization of soil phosphorous (Smith and Read, 2008). However, the reduction in the microbial activities assayed newly showed the suppressive effect of $F$. mosseae, as the markers for PLFAs and NLFA previously suggested. Nevertheless, the stabilized organic matter supplied by adding MDOR amendments was shown to be a key factor in the enhancement of $\beta$-glucosidase and arylsulphatase activities in the rhizosphere of wheat plants when AM fungus was present. These increases might be attributed to a synergistic effect, due to the input of high content in organic $\mathrm{C}$ substances supplied by adding MDOR along with a better stability of soil aggregates promoted by AM fungi. A similar response has been observed during the reclamation of metal-polluted soils by adding organic amendments and AM fungus inoculations (Alguacil et al., 2008; Kholer et al., 2016).

\subsection{Root and soil colonization by AM fungi}

The AM fungi diversity composition in metal-polluted sites has been observed to significantly increase when organic amendments are added; however, the susceptibility of roots to be colonized depends on the plant species (Alguacil et al., 2011). In our study, the MDOR amendment application did not result in significant increases in terms of percentage of root colonization. However, the increased values found in the extraradical mycelium by adding MDOR_Cp suggested that this amendment boosted the colonization of AM fungi as the result of the higher solubilization of nutrients which stimulated the hyphae growth or led to a more suitable physical growing space for AM fungi, as suggested by Zornoza et al. (2015; 2016). This result 
would be also supported by the previous evidences reporting the proliferation of AM fungi related-NLFA when MDOR amendments were added. The dominance and abundance of $F$. mosseae has been reported in hostile metal-polluted environments (Zarei et al., 2010; Alguacil et al., 2011). In our study, the soil colonization by AM fungi was confirmed by the highest values recorded in the extraradical mycelium as the result of the F. mosseae inoculation to this metalpolluted soil. This fact is contradictory with the previous decline reported in the AM fungi population, as the AM fungi related-NLFA revealed, which indicated the suppressive effect of $F$. mosseae, as Tojander et al. (2007) and Welc et al. (2010) suggested. The NLFA 16:1 $\omega 5$, used in this study, has been reported to be more sensitive than PLFA 16:1 105 as indicator of AM mycelia in soil system. This marker is connected with the accumulation of neutral lipids in the vesicles and spores that are the main storage products in AM fungi (Olsson et al., 2003). A possible explanation of this contradictory result in our experiment would be a degradation of a large proportion of storage lipids as the result of the fungal catabolism when is deprived of their usual energy source in the root, or it could be due to the consumption by other organism. However, a further research will be needed in order to verify this hypothesis. The similar values found in the percentage of root colonization in the presence or absence of AM fungus might indicate that the root colonization susceptibility depends on the type of plant species. Sampedro et al. (2008) reported a higher percentage of alfalfa root colonization in contrast to those observed in tomato roots. The ability of AM fungi to colonize this metal-polluted soil was strongly favored by the additive effect of combining, MDOR_Cp and $F$. mosseae. However, the contribution of AM fungi, in terms of percentage of root colonization, would be only evidenced by the beneficial application of MDOR_Cp, suggesting a synergistic effect between the combined treatment and wheat plants. 


\section{Conclusion}

In this study, we evaluated the sustainability of combining treatment involving MDOR amendment application with $F$. mosseae inoculation in the restoration of ecological functions of a metal-polluted soil. Our results demonstrated that MDOR_Pc and MDOR_Cp amendment applications showed similarities in improving the quality and function in this polluted soil, as indicated by the higher values reached in the organic soluble $\mathrm{C}$ fractions, markers for PLFAs, and NLFA and microbial activity. Therefore, the different fungal ability, during the mycoremediation, would not lead to differences in relation to the degree of organic matter humification. Contrary to expectations, the inoculation of $F$. mosseae seemed to have a negative impact on the composition

and activity of microbial populations. However, the combined treatment of MDOR amendment application and AM fungus inoculation resulted in the apparently fully functional soil microbiota in this metal-polluted soil. As well, AM fungi root and soil colonization was efficiently achieved through this treatment as the result of favorable nutritional and spatial conditions. Therefore, the combined treatment, MDOR amendments and $F$. mossease, might be suggested as restoration practice due to its beneficial impact on soil microbial composition and functionality which in turn represent soil attributes of ecological relevance for monitoring reclamation programs.

\section{Acknowledgments}

This work was supported by SoWa Research Infrastructure funded by MEYS CZ grant LM2015075, program "Projects of Large Infrastructure for Research, Development, and Innovations". The authors would also like to thank the grant project of the National Agency for Agricultural Research QK1710379. 


\section{References}

Alburquerque, J.A., de la Fuente, C., Bernal, M.P., 2011. Improvement of soil quality after "alperujo" compost application to two contaminated soils characterized by differing heavy metal solubility. J. Environ. Manage. 92, 733-741.

Alguacil, M.M., Caravaca, F., Azcón, R., Roldán, A., 2008. Changes in biological activity of a degraded Mediterranean soil after using microbially-treated dry olive cake as a biosolid amendment and arbuscular mycorrhizal fungi. Eur. J. Soil Biol. 44, 347-354.

Alguacil, M.M., Torrecillas, E., Caravaca, F., Fernández, D.A., Azcón, R., Roldán, A., 2011. The application of an organic amendment modifies the arbuscular mycorrhizal fungal communities colonizing native seedlings grown in a heavy-metal-polluted soil. Soil Biol. Biochem. 43, 1498-1508.

Alvarenga, P., Gonzalves, A.P., Fernandes, R.M., de Varennes, A., Vallini, G., Duarte, E., CunhaQueda, A.C., 2008. Evaluation of composts and liming materials in the phytostabilization of a mine soil using perennial ryegrass. Sci. Total Environ. 406, 43-56.

Artursson, V., Finlay, R.D., Jansson, J.K., 2006. Interactions between arbuscular mycorrhizal fungi and bacteria and their potential for stimulating plant growth. Environ. Microbiol. 8, 1-10.

Bååth, E., Anderson, T.H., 2003. Comparison of soil fungal/bacterial ratios in a pH gradient using physiological and PLFA-based techniques. Soil Biol. Biochem. 35, 955-963.

Bird, J.A., Herman, D.J., Firestone, M.K., 2011. Rhizosphere priming of soil organic matter by bacterial groups in a grassland soil. Soil Biol. Biochem. 43, 718-725.

Bligh, E.G., Dyer,W.J., 1959. A rapid method of total lipid extraction and purification. Can. J. Biochem. Phys. 37, 911e917. 
Calvarro, L.M., de Santiago-Martín, A., Quirós Gómez, J., González-Huecas, C., Quintana, J.R., Vázquez, A., Lafuente, A.L., Rodríguez Fernández, T.M., Ramírez Vera, R., 2014. Biological activity in metal-contaminated calcareous agricultural soils: the role of the organic matter composition and the particle size distribution. Environ. Sci. Pollut. Res. 21, 61766187.

Covino, S., Fabianová, T., Křesinová, Z., Čvančarová, M., Burianová, E., Filipová, A., Vořisková, J., Baldria, P., Cajthaml, T., 2016. Polycyclic aromatic hydrocarbons degradation and microbial community shifts during co-composting of creosote-treated wood. J. Hazard. Mater. 301, 17-26.

Jones D.L., Nguyen, C., Finlay, R.D., 2009. Carbon flow in the rhizosphere: carbon trading at the soilroot interface. Plant Soil 321, 5-33.

Epelde, L., Burges, A., Mijangos, I., Garbisu, C., 2014. Microbial properties and attributes of ecological relevance for soil quality monitoring during a chemical stabilization field study. Appl. Soil Ecol. 75, 1-12.

Eivazi, F., Tabatabai, M.A., 1977.Phosphatases in soils, Soil Biol. Biochem. 9, 167e172.

Eivazi, F., Tabatabai, M.A., 1988. Glucosidases and galactosidases in soils, Soil Biol. Biochem. $20,601 \mathrm{e} 606$.

FAO, World Reference Base for Soil Resources, FAO, Rome, 2006.

Fernández, D.A., Roldán, A., Azcón, R., Caravaca, F., Bååth, E., 2012. Effects of water stress, organic amendment and mycorrhizal inoculation on soil microbial community structure and activity during the establishment of two heavy metal-tolerant native plant species. Microb. Ecol. 63, 794-803.

Fitter, A.H., Helgason, T., Hodge, A., 2011. Nutritional exchanges in the arbuscular mycorrhizal symbiosis: Implications for sustainable agriculture. Fungal Biol. Rev. 25, 68-72. 
Garcia, C., Hernandez, T., Costa, F., 1997. Potential use of dehydrogenase activity as an index of microbial activity in degraded soils. Commun. S. Sci. Plant. Anal. 28, 123-134

García-Sánchez, M., Palma, J.M., Ocampo, J.A., García-Romera, I., Aranda, E., 2014. Arbuscular mycorrhizal fungi alleviate oxidative stress induced by ADOR and enhance antioxidant responses of tomato plants. J. Plant Physiol. 171, 421-428.

García-Sánchez, M., García-Romera, I., Száková, J., Kaplan, L., Tlustoš, P., 2015a. The effectiveness of various treatments in changing the nutrient status and bioavailability of risk elements in multi-element contaminated soil. Environ. Sci. Pollut. Res. 22, 14325-14336.

García-Sánchez, M., Garcia-Romera, I., Cajthaml, T., Tlustoš, P., Száková, J., 2015b. Changes in soil microbial community functionality and structure in a metal-polluted site: The effect of digestate and fly ash applications. J. Environ. Manage. 162, 63-73.

Giller, K.E., Witter, E., McGrath, S.P., 2009. Heavy metals and soil microbes. Soil Biol. Biochem. 41, 2031-2037.

Giovannetti, M., Mosse, B., 1980. An evaluation of techniques for measuring vesicular-arbuscular mycorrhizal infection in roots. New Phytol. 84, 489-500.

Hildebrandt, U., Regvar, M., Bothe, H., 2007. Arbuscular mycorrhiza and heavy metal tolerance. Phytochemistry 68, 139-146.

Hodge, A., Fitter, A.H., 2010. Substantial nitrogen acquisition by arbuscular mycorrhizal fungi from organic material has implications for N cycling. PNAS 107, 13754-13759.

Hovorka, M., Száková, J., García-Sánchez, M., Acebal, M.B., García-Romera, I., Tlustoš, P., 2016. Risk element sorption/desorption characteristics of dry olive residue: a technique for the potential immobilization of risk elements in contaminated soils. Environ. Sci. Pollut. Res. $23,22614-22622$. 
Kohler, J., Caravaca, F., Azcón, R., Díaz, G., Roldán, A., 2016. Suitability of the microbial community composition and function in a semiarid mine soil for assessing phytomanagement practices based on mycorrhizal inoculation and amendment addition. J. Environ. Manag. 169, 236-246.

Ladd, J.N., Butler, J.H.A., 1972. Short-term assays of soil proteolytic enzyme activities using proteins and dipeptide derivatives as substrates. Soil Biol. Biochem. 4, 19e30.

Leigh, J., Fitter, A.H., Hodge, A., 2011. Growth and symbiotic effectiveness of an arbuscular mycorrhizal fungus in organic matter in competition with soil bacteria. FEMS Microbiol. Ecol. 76, 428-438.

López-Piñeiro, A., Albarrán, A., Rato Nunes, J.M., Peña, D., Cabrera, D., 2011. Long-term impacts of de-oiled two-phase olive mill waste on soil chemical properties, enzyme activities and productivity in an olive grove. Soil Tillage Res. 114, 175-182.

Meier, S., Borie, F., Bolan, N., Cornejo, P., Meier, S.A., 2012. Phytoremediation of Metal-Polluted Soils by Arbuscular Mycorrhizal Fungi Phytoremediation of Metal-Polluted Soils by Arbuscular Mycorrhizal Fungi. Crit. Rev. Environ. Sci. Technol. 427.

Mingorance, M.D., Barahona, E., Fernández-Gálvez, J., 2007. Guidelines for improving organic carbon recovery by the wet oxidation method. Chemosphere $68,409 \mathrm{e} 413$.

Montiel-Rozas, M.., López-García, Á., Kjøller, R., Madejón, E., Rosendahl, S., 2016. Organic amendments increase phylogenetic diversity of arbuscular mycorrhizal fungi in acid soil contaminated by trace elements. Mycorrhiza 26, 575-585.

Nielsen, M.N., Winding, A., 2002. Microorganisms as Indicators of Soil Health. National Environmental Research Institute, Denmark. Technical Report.

Olsson, P.A., Larsson, L., Bago, B.Wallander, H., Van Aarle, I.M., 2003. Ergosterol and fatty acids for estimation of mycorrhizal fungi. New Phytol. 1, 7-10. 
Pardo, T., Clemente, R., Bernal, M.P., 2011. Effects of compost, pig slurry and lime on trace element solubility and toxicity in two soils differently affected by mining activities. Chemosphere 84, 642-650.

Pardo, T., Clemente, R., Epelde, L., Garbisu, C., Bernal, M.P., 2014. Evaluation of the phytostabilisation efficiency in a trace elements contaminated soil using soil health indicators. J. Hazard. Mater. 268, 68-76.

Paterson, E., Sim, A., Davidson, J., Daniell, T.J., 2016. Arbuscular mycorrhizal hyphae promote priming of native soil organic matter mineralisation. Plant Soil 408, 243-254.

Philippot, L., Raaijmakers, J.M., Lemanceau, P., Van der Putten, W.H., 2013. Going back to the roots: the microbial ecology of the rhizosphere. Nat. Nat. Rev. Microbiol. 11, 789-799.

Phillips, J.M., Hayman, D.S., 1970. Improved procedures for clearing roots and staining parasitic and vesicular-arbuscular mycorrhizal fungi for rapid assessment of infection. Trans. Br. Mycol. Soc. 55, 158-161.

Reina, R., Liers, C., Ocampo, J.A., García-Romera, I., Aranda, E., 2013. Solid state fermentation of olive mill residues by wood- and dung-dwelling Agaricomycetes: Effects on peroxidase production, biomass development and phenol phytotoxicity. Chemosphere 93, 1406-1412.

Reina, R., Liers, C., García-Romera, I., Aranda, E., 2017. Enzymatic mechanisms and detoxification of dry olive-mill residue by Cyclocybe aegerita, Mycetinis alliaceus and Chondrostereum purpureum 117, 89-96.

Rodríguez-Caballero, G., Caravaca, F., Fernández-González, A.J., Alguacil, M.M., FernándezLópez, M., Roldán, A., 2017. Arbuscular mycorrhizal fungi inoculation mediated changes in rhizosphere bacterial community structure while promoting revegetation in a semiarid ecosystem. Sci. Total Environ. 1-11. 
Sampedro, I., Aranda, E., Martín, J., García-Garrido, J.M., García-Romera, I., Ocampo, J.A., 2004.

Saprobic fungi decrease plant toxicity caused by olive mill residues. Appl. Soil Ecol. 26, $149-156$.

Sampedro, I., Marinari, S., D’Annibale, A., Grego, S., Ocampo, J.A., García-Romera, I., 2007.

Organic matter evolution and partial detoxification in two-phase olive mill waste colonized by white-rot fungi. Int. Biodeterior. Biodegrad. 60, 116-125.

Sampedro, I., Aranda, E., Díaz, R., García-Sanchez, M., Ocampo, J.A., García-Romera, I., 2008. Saprobe fungi decreased the sensitivity to the toxic effect of dry olive mill residue on arbuscular mycorrhizal plants. Chemosphere 70, 1383-1389.

Sampedro, I., Cajthaml, T., Marinari, S., Petruccioli, M., Grego, S., D’Annibale, A., 2009a. Organic matter transformation and detoxification in dry olive mill residue by the saprophytic fungus Paecilomyces farinosus. Process Biochem. 44, 216-225.

Sampedro, I., Giubilei, M., Cajthaml, T., Federici, E., Federici, F., Petruccioli, M., D’annibale, A., 2009b. Short-term impact of dry olive mill residue addition to soil on the resident microbiota. Bioresour. Technol. 100, 6098-6106.

Siles, J.A., Cajthaml, T., Hernández, P., Pérez-Mendoza, D., García-Romera, I., Sampedro, I., 2014a. Shifts in Soil Chemical Properties and Bacterial Communities Responding to Biotransformed Dry Olive Residue Used as Organic Amendment. Microb. Ecol. 70, 231243.

Siles, J.A., Pérez-Mendoza, D., Ibáñez, J.A., Scervino, J.M., Ocampo, J.A., García-Romera, I., Sampedro, I., 2014b. Assessing the impact of biotransformed dry olive residue application to soil: Effects on enzyme activities and fungal community. Int. Biodeterior. Biodegradation 89, 15-22.

Smith, S.E., Read, D.J., 2008. Mycorrhizal Symbiosis, Soil Science Society of America Journal. 
Tabatabai, M.A., Bremmer, J.M., 1970. Arylsulphatase activity of soils. Soil Sci. Soc. Am. Pro 34, $225 \mathrm{e} 229$.

Toljander, J.F., Lindahl, J.D., Leslie R., Paul, M.E., Roger D.F., 2007. Influence of arbuscular mycorrhizal mycelial exudates on soil bacterial growth and community structure. FEMS Microbiol. Ecol. 61, 295-304.

Vaněk, A., Boruvka, L., Drabek, O., Mihaljevic, M., Komarek, M., 2005. Mobility of lead, zinc and cadmium in alluvial soils heavily polluted by smelting industry. Plant Soil Environ. 51, $316 \mathrm{e} 321$.

Veresoglou, S.D., Rilling, M.C., 2011. Suppression of fungal and nematode plant pathogens through arbuscular mycorrhizal fungi. Biol. Lett. 8, 214-217.

Welc, M., Ravnskov, S., Kieliszewska-Rokicka, B., Larsen, J., 2010. Suppression of other soil microorganisms by mycelium of arbuscular mycorrhizal fungi in root-free soil. Soil Biol. Biochem. 42, 1534-1540.

Zarei, M., Hempel, S., Wubet, T., Schaer, T., Savaghebi, G., Jouzani, G.S., Nekouei, M.K., Buscot, F., 2010. Molecular diversity of arbuscular mycorrhizal fungi in relation to soil chemical properties and heavy metal contamination. Environ. Pollut. 158, 2757-2765.

Zornoza, R., Acosta, J.A., Martínez-Martínez, S., Faz, A., Bååth, E., 2015. Main factors controlling microbial community structure and function after reclamation of a tailing pond with aided phytostabilization. Geoderma 245, 1-10.

Zornoza, R., Acosta, J.A., Faz, A., Bååth, E., 2016. Microbial growth and community structure in acid mine soils after addition of different amendments for soil reclamation. Geoderma 272, 64-72. 

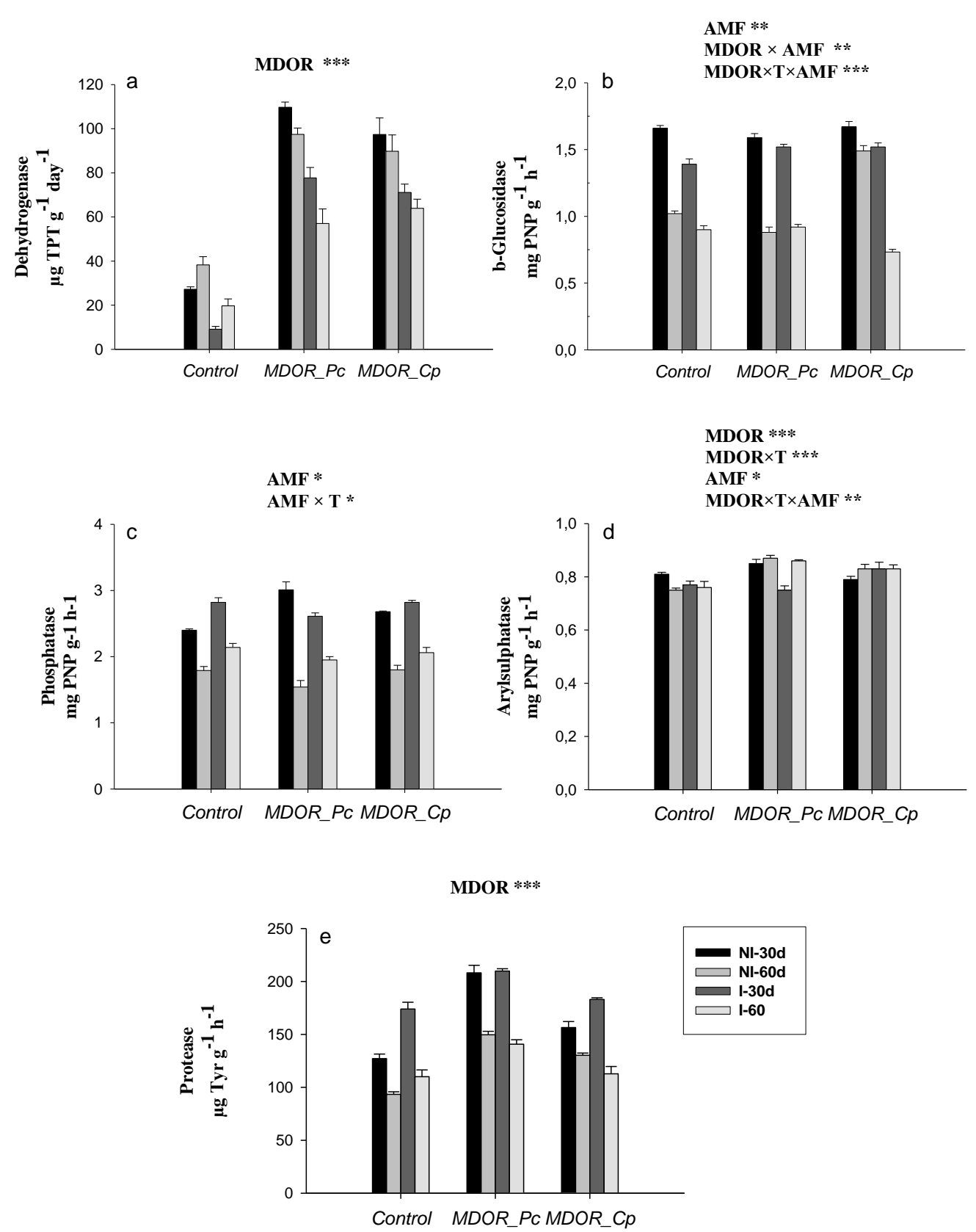

Figure 1. Dehydrogenase (DH), $\beta$-glucosidase ( $\beta$-Glu), phosphatase (Phos), arylsulphatase (Aryl), and protease (Pro) activity in metal-polluted soil samples in response to MDOR amendment (MDOR_Ff, MDOR_Pc, MDOR_Ba, and MDOR_Cp) application and F. mosseae (AMF) inoculation after 30 and 60 days of experiment $(\mathrm{T})$. Values represent the mean \pm standard deviation of four replicates $(n=4)$. 

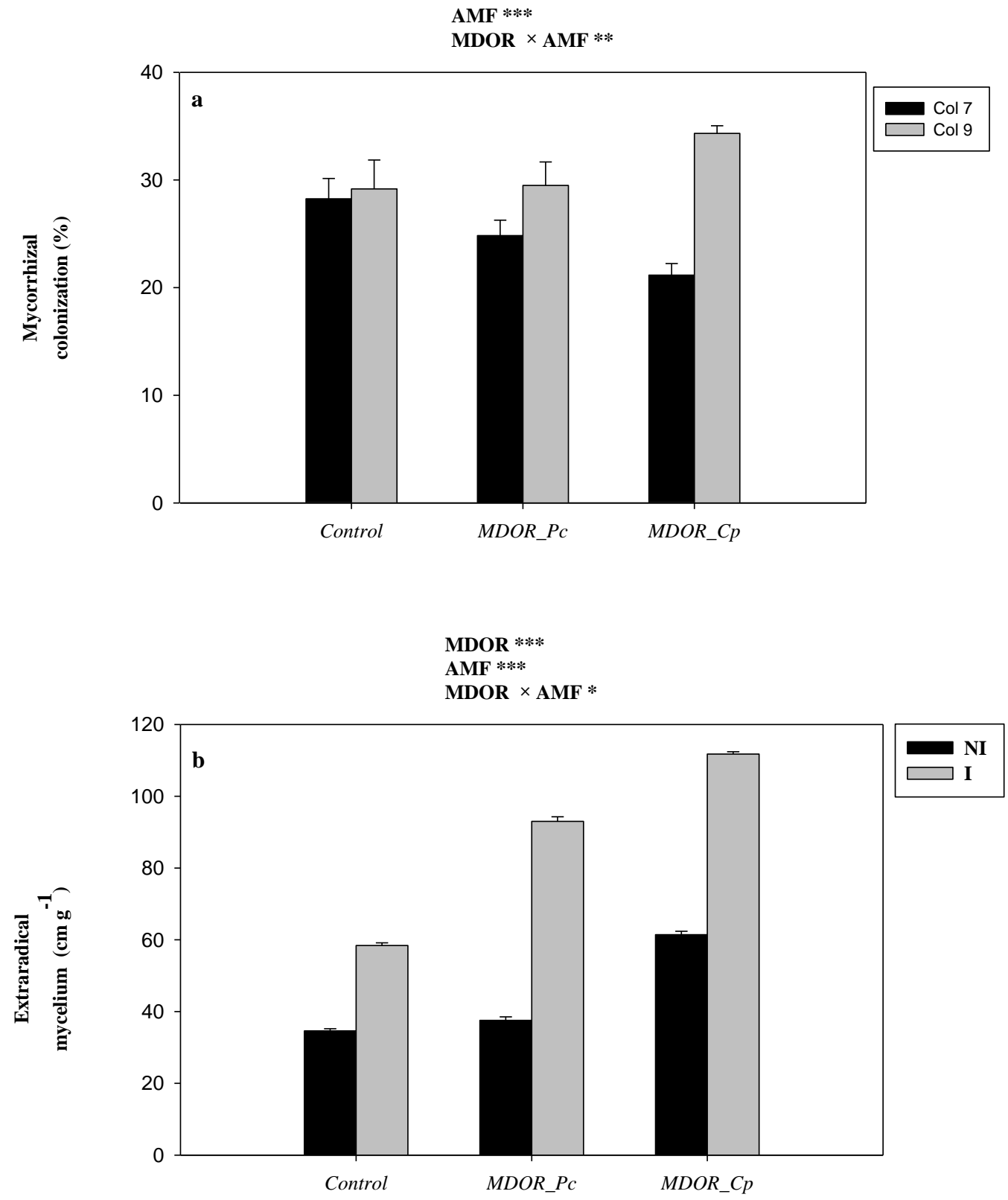

Figure 2. Percentage of root colonization (a) and external mycorrhizal mycelium (b) in metalpolluted soil samples in response to MDOR amendments (MDOR_Ff, MDOR_Pc, MDOR_Ba, and MDOR_Cp) application and F. mosseae (AMF) inoculation at 60 days of experiment. Values represent the mean $( \pm S E)$ of four replicates $(n=4)$. 
Table 1. Physico-chemical characteristics of DOR and MDOR amendments $(n=3)$. n.d. Not detected

\begin{tabular}{|c|c|c|c|}
\hline & Soil & MDOR_Pc & MDOR_Cp \\
\hline pH & $7.14 \pm 0.17$ & $6.50 \pm 0.02$ & $6.93 \pm 0.01$ \\
\hline CEC (mmoles kg) & $149.11 \pm 2.53$ & $518.40 \pm 16.28$ & $610.62 \pm 12.55$ \\
\hline $\mathrm{C}_{\text {tot }}\left(\mathrm{g} \mathrm{kg}^{-1}\right)$ & $38.53 \pm 0.67$ & $472.20 \pm 3$ & $462.40 \pm 2.72$ \\
\hline $\mathbf{N}_{\text {tot }}\left(\mathrm{g} \mathrm{kg}^{-1}\right)$ & $3.13 \pm 0.04$ & $22.10 \pm 0.50$ & $28.20 \pm 1.40$ \\
\hline $\mathbf{C} / \mathbf{N}$ & $12.30 \pm 0.14$ & $21.37 \pm 0.41$ & $16.44 \pm 0.77$ \\
\hline TOC ( $\left.\mathrm{g} \mathrm{kg}^{-1}\right)$ & $17.12 \pm 0.42$ & $131.10 \pm 6.80$ & $160 \pm 4.46$ \\
\hline Phenols (g kg-1) & n.d & $52.97 \pm 4.54$ & $44.91 \pm 4.34$ \\
\hline Ergosterol $(\mu \mathrm{M})$ & $6.80 \pm 0.2$ & $50 \pm 7.19$ & $39 \pm 5.22$ \\
\hline$P\left(\mathrm{mg} \mathrm{kg}^{-1}\right)$ & $272 \pm 19.60$ & $984.66 \pm 32.26$ & $536.66 \pm 20.28$ \\
\hline $\mathrm{K}\left(\mathrm{g} \mathrm{kg}^{-1}\right)$ & $3.04 \pm 0.10$ & $6.72 \pm 0.65$ & $8.05 \pm 0.70$ \\
\hline $\operatorname{Mg}\left(\mathrm{g} \mathrm{kg}^{-1}\right)$ & $1.95 \pm 0.07$ & $0.71 \pm 0.01$ & $0.64 \pm 0.03$ \\
\hline $\mathrm{Ca}\left(\mathrm{g} \mathrm{kg}^{-1}\right)$ & $2.30 \pm 0.08$ & $1.40 \pm 0.03$ & $1.67 \pm 0.07$ \\
\hline $\mathrm{S}\left(\mathrm{mg} \mathrm{kg}^{-1}\right)$ & $186.66 \pm 14.81$ & $590 \pm 14.63$ & $434 \pm 15$ \\
\hline $\mathrm{Fe}\left(\mathrm{g} \mathrm{kg}^{-1}\right)$ & $15.60 \pm 0.35$ & $0.18 \pm 0.04$ & $0.50 \pm 0.36$ \\
\hline $\operatorname{Mn}\left(\mathrm{mg} \mathrm{kg}^{-1}\right)$ & $1713 \pm 78$ & $5.34 \pm 0.20$ & $7.10 \pm 1.90$ \\
\hline Zn $\left(\mathbf{m g ~ k g}{ }^{-1}\right)$ & $1937 \pm 76.61$ & $14.24 \pm 3.40$ & $40.26 \pm 27.44$ \\
\hline $\mathrm{Cd}\left(\mathrm{mg} \mathrm{kg}{ }^{-1}\right)$ & $13.7 \pm 1.40$ & n.d & n.d \\
\hline $\mathrm{Cr}\left(\mathrm{mg} \mathrm{kg}{ }^{-1}\right)$ & $17.63 \pm 1.06$ & $1.01 \pm 0.07$ & $1.13 \pm 0.20$ \\
\hline $\mathrm{Cu}\left(\mathrm{mg} \mathrm{kg}{ }^{-1}\right)$ & $30.26 \pm 2.45$ & $7 \pm 0.13$ & $6.62 \pm 0.36$ \\
\hline Pb (mg kg-1) & $1603 \pm 65.65$ & n.d & n.d \\
\hline
\end{tabular}


Table 2. Microbiological properties microbial activities in soil $(n=3)$.

\begin{tabular}{|c|c|}
\hline & Fluvisol \\
\hline PLFAt tot $_{\left(\mathrm{mg} \mathrm{kg}^{-1}\right)}$ & $2.40 \pm 0.70$ \\
\hline PLFAfun $\left(\mathrm{mg} \mathrm{kg}^{-1}\right)$ & $0.011 \pm 0.0021$ \\
\hline $\operatorname{PLFAbac~}_{\text {bl }}\left(\mathrm{mg} \mathrm{k}^{-1}\right)$ & $1.53 \pm 0.50$ \\
\hline PLFAact $_{\text {(mg kg-1) }}$ & $0.32 \pm 0.08$ \\
\hline $\operatorname{PLFAGram+}\left(\mathrm{mg} \mathrm{kg}^{-1}\right)$ & $0.36 \pm 0.23$ \\
\hline PLFAGram- $\left(\mathrm{mg} \mathrm{kg}^{-1}\right)$ & $0.74 \pm 0.16$ \\
\hline NLFAAMF (mg kg-1) & $5.60 \pm 1.93$ \\
\hline Dehydrogenase $\left(\mu \mathrm{g}\right.$ TPF $\mathrm{g}^{-1}$ day $\left.^{-1}\right)$ & $8.62 \pm 5$ \\
\hline$\beta$-Glucosidase (mg PNP g-1 $\mathrm{h}^{-1}$ ) & $1.29 \pm 0.27$ \\
\hline Phosphatase (mg PNP g $\mathrm{g}^{-1} \mathrm{~h}^{-1}$ ) & $2.52 \pm 0.14$ \\
\hline Arylsulphatase $\left(\mu \mathrm{g} \mathrm{PNP}^{-1} \mathrm{~h}^{-1}\right)$ & $901.87 \pm 102.15$ \\
\hline Protease $\left(\mu \mathrm{g}\right.$ Tyr $\left.\mathrm{g}^{-1} \mathrm{~h}^{-1}\right)$ & $24.23 \pm 5.6$ \\
\hline
\end{tabular}


Table 3. Soil chemical variables measured in metal-polluted soil samples in response to MDOR amendment (MDOR_Ff, MDOR_Pc, MDOR_Ba, and MDOR_Cp) application and F. mosseae (AMF) inoculation after 30 and 60 days of experiment (T). Values represent the mean \pm standard deviation of four replicates $(n=4)$.

\begin{tabular}{|c|c|c|c|c|c|c|c|}
\hline & \multicolumn{3}{|c|}{ Control } & \multicolumn{2}{|c|}{ MDOR_Pc } & \multicolumn{2}{|c|}{ MDOR_Cp } \\
\hline & $\mathbf{T}$ & -AMF & $+\mathrm{AMF}$ & -AMF & +AMF & -AMF & +AMF \\
\hline $\mathrm{C}_{\text {tot }}$ & 30 & $35.24 \pm 1.24$ & $37.83 \pm 3.10$ & $46.35 \pm 3.52$ & $43.77 \pm 4.25$ & $44.02 \pm 1.97$ & $42.14 \pm 1.79$ \\
\hline$\left(\mathrm{g} \mathrm{kg}^{-1}\right)$ & 60 & $40.05 \pm 1.88$ & $35.52 \pm 0.61$ & $39.37 \pm 2.41$ & $37.87 \pm 0.85$ & $41.91 \pm 2.77$ & $38.56 \pm 0.74$ \\
\hline TOC & 30 & $16.81 \pm 0.44$ & $18.38 \pm 3.34$ & $20 \pm 0.72$ & $18.37 \pm 0.61$ & $18.80 \pm 0.76$ & $19.27 \pm 0.43$ \\
\hline$\left(\mathrm{g} \mathrm{kg}^{-1}\right)$ & 60 & $17.03 \pm 0.38$ & $16.93 \pm 0.52$ & $19.30 \pm 0.57$ & $19.48 \pm 0.65$ & $20.23 \pm 1.50$ & $19.60 \pm 1.07$ \\
\hline WSOC & 30 & $5.12 \pm 0.54$ & $4.14 \pm 0.20$ & $6.44 \pm 0.47$ & $5.90 \pm 0.66$ & $5.67 \pm 0.48$ & $4.88 \pm 0.77$ \\
\hline$\left(\mathrm{g} \mathrm{kg}^{-1}\right)$ & 60 & $1.92 \pm 0.47$ & $1.60 \pm 0.62$ & $2.98 \pm 0.72$ & $3.26 \pm 0.16$ & $3.52 \pm 0.30$ & $2.60 \pm 0.52$ \\
\hline $\mathbf{N}_{\text {tot }}$ & 30 & $2.85 \pm 0.14$ & $3.08 \pm 0.23$ & $3.73 \pm 0.20$ & $3.52 \pm 0.24$ & $3.52 \pm 0.17$ & $3.40 \pm 0.13$ \\
\hline$\left(\mathrm{g} \mathrm{kg}^{-1}\right)$ & 60 & $3.35 \pm 0.13$ & $2.83 \pm 0.09$ & $3.10 \pm 0.17$ & $3.11 \pm 0.08$ & $3.18 \pm 0.09$ & $3.17 \pm 0.13$ \\
\hline
\end{tabular}


Table 4. Abundance and composition of phospholipids (PLFA) and neutral lipids fatty acids (NLFA) in metal-polluted soil samples in response to MDOR amendment (MDOR_Pcand MDOR_Cp) application and F. mosseae (AMF) inoculation after 30 and 60 days of experiment $(\mathrm{T})$. Values represent the mean \pm standard deviation of five replicates $(n=5)$.

\begin{tabular}{|c|c|c|c|c|c|c|c|}
\hline & \multicolumn{3}{|c|}{ Control } & \multicolumn{2}{|c|}{ MDOR_Pc } & \multicolumn{2}{|c|}{ MDOR_Cp } \\
\hline & $\mathbf{T}$ & $-\mathbf{A M F}$ & $+\mathrm{AMF}$ & -AMF & $+\mathrm{AMF}$ & -AMF & $+\mathrm{AMF}$ \\
\hline PLFAt tot & 30 & $3.70 \pm 0.84$ & $4.34 \pm 0.64$ & $10.10 \pm 1.60$ & $2.24 \pm 0.43$ & $12.11 \pm 0.44$ & $2.70 \pm 0.82$ \\
\hline$\left(\mathrm{mg} \mathrm{kg}^{-1}\right)$ & 60 & $6.40 \pm 0.26$ & $2.22 \pm 0.73$ & $11.43 \pm 1.52$ & $3.88 \pm 0.33$ & $10.60 \pm 1.00$ & $4.40 \pm 0.73$ \\
\hline & 30 & $0.01 \pm 0.006$ & $0.02 \pm 0.004$ & $0.26 \pm 0.09$ & $0.01 \pm 0.005$ & $0.26 \pm 0.08$ & $0.01 \pm 0.01$ \\
\hline $\begin{array}{l}\text { PLFAfun } \\
\left(\mathrm{mg} \mathrm{kg}^{-1}\right)\end{array}$ & 60 & $0.03 \pm 0.009$ & $0.04 \pm 0.006$ & $0.23 \pm 0.05$ & $0.02 \pm 0.006$ & $0.27 \pm 0.05$ & $0.03 \pm 0.02$ \\
\hline PLFAbac & 30 & $1.70 \pm 0.60$ & $3.00 \pm 0.10$ & $7.11 \pm 0.60$ & $1.50 \pm 0.30$ & $8.24 \pm 0.06$ & $1.63 \pm 0.60$ \\
\hline$\left(\mathrm{mg} \mathrm{kg}^{-1}\right)$ & 60 & $4.60 \pm 0.24$ & $1.51 \pm 0.12$ & $7.70 \pm 0.94$ & $2.43 \pm 0.22$ & $7.01 \pm 0.61$ & $2.82 \pm 0.51$ \\
\hline PLFAact & 30 & $0.35 \pm 0.11$ & $0.42 \pm 0.05$ & $0.75 \pm 0.08$ & $0.30 \pm 0.06$ & $0.77 \pm 0.15$ & $0.24 \pm 0.03$ \\
\hline$\left(\mathrm{mg} \mathrm{kg}^{-1}\right)$ & 60 & $0.60 \pm 0.06$ & $0.27 \pm 0.09$ & $1.02 \pm 0.20$ & $0.45 \pm 0.06$ & $0.92 \pm 0.11$ & $0.44 \pm 0.09$ \\
\hline PLFAGram+ & 30 & $0.27 \pm 0.11$ & $0.81 \pm 0.09$ & $1.50 \pm 0.32$ & $0.25 \pm 0.05$ & $2.72 \pm 0.10$ & $0.35 \pm 0.20$ \\
\hline$\left(\mathrm{mg} \mathrm{kg}^{-1}\right)$ & 60 & $1.88 \pm 0.10$ & $0.42 \pm 0.04$ & $2.40 \pm 0.10$ & $0.67 \pm 0.07$ & $1.80 \pm 0.14$ & $0.80 \pm 0.16$ \\
\hline PLFAGram- & 30 & $0.98 \pm 0.20$ & $1.52 \pm 0.10$ & $3.60 \pm 0.45$ & $0.81 \pm 0.17$ & $3.43 \pm 1.11$ & $0.76 \pm 0.26$ \\
\hline$\left(\mathrm{mg} \mathrm{kg}^{-1}\right)$ & 60 & $1.84 \pm 0.09$ & $0.52 \pm 0.18$ & $4.36 \pm 0.26$ & $1.13 \pm 0.09$ & $3.68 \pm 0.13$ & $1.34 \pm 0.27$ \\
\hline NLFA $_{\text {AMF }}$ & 30 & $1.48 \pm 0.33$ & $0.88 \pm 0.15$ & $4.06 \pm 0.72$ & $2.00 \pm 0.32$ & $4.12 \pm 0.44$ & $3.00 \pm 0.33$ \\
\hline$\left(\mathrm{mg} \mathrm{kg}^{-1}\right)$ & 60 & $3.16 \pm 0.27$ & $1.50 \pm 0.10$ & $6.34 \pm 0.34$ & $0.76 \pm 0.18$ & $3.95 \pm 0.46$ & $1.10 \pm 0.40$ \\
\hline
\end{tabular}


Table 5. Physiological stress markers in metal-polluted soil samples in response to MDOR amendment (MDOR_Ff, MDOR_Pc, MDOR_Ba, and MDOR_Cp) application and F. mosseae (AMF) inoculation after 30 and 60 days of experiment (T). Values represent the mean \pm standard deviation of five replicates $(n=5)$.

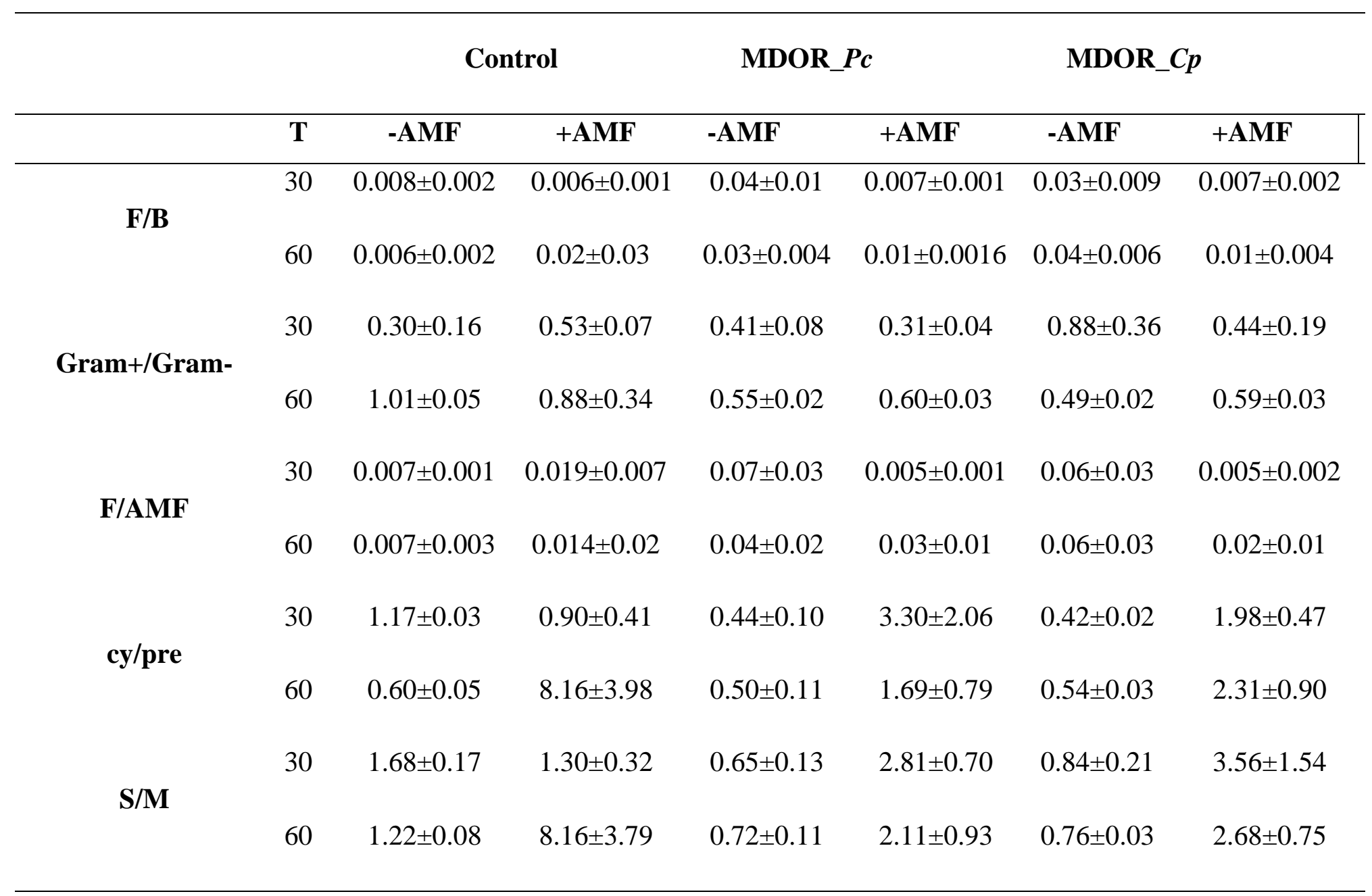

